https://doi.org/10.4316/CC.2020.02.006

\title{
RISING MIDDLE POWERS: COMPARATIVE ANALYSIS OF MIKTA COUNTRIES
}

\author{
Hülya KINIK \\ Karadeniz Technical University, Turkey \\ E-mail: hulya.ercan@ktu.edu.tr
}

\begin{abstract}
With the beginning of the $21^{\text {st }}$ Century, the structure of the liberal economic order and its institutions have undergone a great transformation. Since the global financial crisis in 2008, some Asian and Latin American countries draw attention with their rapidly growing economic performances raising big debates over "the West and the rest" discourse. On the other hand, the matter and the uncertainty of the conceptualisation and identification of these new rising powers have been generally ignored. In order to identify rising middle powers, not only their material capacities but also the roles they assign for themselves in international politics (identity definitions) and global policy behaviours are significant determinants. These countries have an important status in the international arena by combining their "positional" (material powers) and "behavioral" (ideological power, policies they pursue) powers. MIKTA members can play a more active role in foreign policy thanks to their material (military, economic, GDP, geographical location, diplomatic capacity...) and ideational (soft power, effectiveness) power capacities. However, after seven years of its establishment, the effectiveness, credibility, and legitimacy of the group have come under question by some analysts. In this backdrop, this paper attempts to compare the potentials of MIKTA countries with material and behavioural patterns that are related to middle power concepts and seeks to find trends in growth or decline in these five countries and to assess MIKTA's prospects on its sustainability.
\end{abstract}

Keywords: Rising Middle Powers, G20, MIKTA, economic performance, hard power, soft power.

Rezumat: Puteri medii în ascensiune: analiza comparativă a țărilor MIKTA. Începutul secolului XXI a adus cu sine mari transformări în structura ordinii economice liberale și a instituțiilor sale. Odată cu criza financiară mondială din 2008, unele țări asiatice și latino-americane au atras atenția asupra performanțele lor economice crescânde, generând astfel dezbateri asupra temei „Occidentul și ceilalți”. Pe de altă parte, problema și incertitudinea conceptualizării și identificării acestor noi puteri în ascensiune au fost, în general, ignorate. Factorii determinanți semnificativi în identificarea puterilor medii aflate

Copyright (c) 2020 “Codrul Cosminului”, XXVI, 2020, No. 2, p. 405-430. 
în ascensiune se referă nu numai la capacitățile lor materiale, ci și la comportamentele politice globale sau la rolurile pe care și le însușesc în politica lor externă (privite ca definiții identitare). Aceste țări au un statut important pe arena internațională prin combinarea puterilor „de poziție” (materiale) și „comportamentale” (ideologii, politici) pe care le urmăresc. Membrii MIKTA pot juca un rol mai activ în politica externă datorită capacităților lor de „puteri materiale” (implicând aspecte militare, economice, PIB, de așezare geografică și capacitate diplomatică) și „ideatice” (exprimată prin soft-power, eficacitate). Cu toate acestea, la șapte ani de la înființare, unii analiști au pus sub semnul întrebării eficacitatea, credibilitatea și legitimitatea grupului. Într-un asemenea context, această lucrare încearcă să compare potențialul țărilor MIKTA cu tiparul material și comportamental specific unei „puteri medii”, identificând tendințe de creștere sau declin în cele cinci țări membre și evaluând perspectivele MIKTA referitoare la sustenabilitatea acesteia.

\section{INTRODUCTION}

Recently, we have been witnessing a significant debate in the global arena on the continuing power transition arising in the international system on behalf of rising powers which have begun to play a substantial role from the dominant powers and to assume on new responsibilities in a major international organisation to change the international system following their values, plans and interests. ${ }^{1}$ In this transformation process, the global financial crisis that emerged in the United States in 2008 deeply affected the global economy at short notice. It became a critical breaking point that has led to a diffusion of power from the Western powers to the global South and exerted immense pressure on the existing world order. Two significant trends have shaped the course of this transformation since the crisis broke out. First of all, some of the analysis claimed that the developed Western powers' ability to maintain economic growth and reflect their political and economic forces at the international level have begun to diminish. Second, the countries that managed to overcome the crisis with relatively mild damages and started to become more active in the global economy by increasing their share in world production became the worldwide economy's dynamo. ${ }^{2}$

${ }^{1}$ Emel Parlar Dal, On Turkey's Trail as a "Rising Middle Power" in the Network of Global Governance: Preferences, Capabilities, and Strategies, in "Perceptions", Vol. XIX, 2014, No. 4, p. 107.

2 Ziya Öniş and Mustafa Kutlay, Demokratik BRICS Ülkeler: Küresel Yönetişimin Yeni Aktörleri, 2011, p. 20, in https://www.academia.edu/19557328/Ziya_\%C3\%96ni\%C5 \%9F_ve_Mustafa_Kutlay_Demokratik_BICS_\%C3\%9Clkeler_K\%C3\%BCresel_Y\%C3\%B 6n eti\%C5\%9Fimin_Yeni_Akt\%C3\%B6rleri, (Accessed on 12.06.2020). 
In such circumstances, middle powers have taken the opportunities of room for manoeuvre and new status at regional and international arenas defined with several concepts such as "multi-multilateralism, minilateralism, and the rise of informals or the GX world". ${ }^{3}$ Rising non-western states are more active in their foreign policies and strong in their region and can be role models. They are willing to increase their voice and presence in international decision-making mechanisms in line with their increasing economic weight. ${ }^{4}$ Given the current developments, growth and potentials of these dynamic countries, according to many analysts, these countries will be the biggest rivals to the developed countries, especially to the hegemony of America-Western Europe in the coming years. Within this context, a new group of middle powers under the name of MIKTA (Mexico, Indonesia, South Korea, Turkey, and Australia) is an example of such informal gatherings.

This study aims to analyse various aspects of MIKTA. Within these frameworks, first, I will present a summary of how and why MIKTA was established. Following this, I will mention about general characteristics and basic facts about the group. Then, I will compare and contrast the group members within the scope of their material capability dimension. Finally, I will discuss the group's impact on the global scene and analyse their potentials and limitations in strengthening global governance and the grouping prospects.

\section{MIKTA: RISE AND GENERAL CHARACTERISTICS}

MIKTA was initiated by the foreign ministers of Mexico, Indonesia, South Korea, Turkey, and Australia at the 68th meeting of the UN General Assembly on 25 September 2013. The group is considered as a consultation and coordination platform rather than as a formal organisation. ${ }^{5}$ The South Korean Foreign Minister described MIKTA as "a middle-power grouping that has common basic values of democracy and free-market economy and desire and has the capacity to promote to the progress of the international community." They also share the view that

\footnotetext{
${ }^{3}$ Stewart M. Patrik and Asley Feng, MIKTA in the Middle: A Little-Known Multilateral Group Turns Five, 2018, in https://www.cfr.org/blog/mikta-middle-little-knownmultilateral-group-turns-five (Accessed on 18.05.2020).

${ }^{4}$ Ziya Öniş and Mustafa Kutlay, op. cit., p. 20; Gilford John Ikenberry, The end of liberal international order?, "International Affairs", Vol. 94, 2018, No. 1, p.19.

${ }^{5}$ Sook-Jong Lee, Chaesung Chun, HyeeJung Suh, Patrick Thomsen, Middle Power in Action: The Evolving Nature of Diplomacy in the Age of Multilateralism. 2015, p. 7, EAI Middle Power Diplomacy Initiative (MPDI), East Asia Institute, https://www.files.ethz.ch/isn/191150/30.04.2015.pdf (Accesed on 22.06.2020).
} 
strong political leadership is necessary to overcome core international problems in the coming years. In this context, they are unique to enable international negotiation and collaboration and bring new perspectives and offer solutions as key economic middle powers. ${ }^{6}$

MIKTA states are all the members of the G20, and they have a relatively similar GDP. All of MIKTA states, except Indonesia, hosted the G20 summits held after the 2008 fiscal crisis. South Korea hosted the G20 meeting in 2010; Mexico in Los Cabos in 2012; Australia in Brisbane in 2014, and Turkey in Antalya in 2015.7 In this context, these new middle powers have the opportunity to gather around the same table with the developed states and bring new issues in the global governance discussions. ${ }^{8}$ Nevertheless, MIKTA members state that they do not aim to form an exclusive bloc, but seek to develop interaction in social and cultural fields by first strengthening economic ties.

Although MIKTA does not have a formal status yet, the group members serve as bridges in several policy spheres, mainly between developed and developing nations; rather than being a threat, they deal with global issues and act as a representative of their regions or similar countries. ${ }^{9}$ MIKTA states aim to work together with non-member countries, regional consultative groups and international organisations, and in the end, open up the opportunity of enlarging its membership. Briefly, four remarkable common characteristics of MIKTA countries can be concealed as follows: ${ }^{10}$

- They have an active role in their regions,

- They belong to the traditional and developing middle powers, none of them is a great or small power,

${ }^{6}$ Mo Jongryn, Introduction: G20 Middle Powers (MIKTA) and Global Governance, pp. 1-13, in Mo Jongryn (Ed.), MIKTA, Middle Powers, and New Dynamics of Global Governance. The G20's Evolving Agenda, New York, Palgrave Macmillan, 2015.

${ }^{7}$ Selçuk Çolakoğlu, MIKTA's Role in the G20, 2016, in http://www.asianpacificcenter.org/mikta-s-role-in-the-g20.html (Accessed on 19.05.2020).

${ }^{8}$ Andrew Fenton Cooper, Emel Parlar Dal, Positioning The Third Wave Of Middle Power Diplomacy: Institutional Elevation, Practice Limitations, "International Journal”, Vol. 71, 2016, No. 4, p.523.

${ }^{9}$ Erdal Tanas Karagöl, Kıtalar Arası Ekonomik İşbirliği: MIKTA, "Seta Perspektif”, 2014, No. 62, p.2; Jorge A. Sciavon and Diego Domínguez, Mexico, Indonesia, South Korea, Turkey, and Australia (MIKTA): Middle, Regional, and Constructive Powers Providing Global Governance. Asia \& the Pacific Policy Studies, Vol. 3, 2016, No. 3, p. 496.

${ }^{10}$ Erdal Tanas Karagöl, op. cit., p. 1. 
- They adopt the open economic model structure,

- They are managed by a pluralist system despite having different regimes.

As of April 2020, the MIKTA group has held 16 meetings of the foreign ministers, 8 meetings of senior officials, and five speakers' consultation. MIKTA countries have adopted seven core areas of collaboration listed as follows: Good Governance and Democracy Counterterrorism, Trade and the Economy, Sustainable Development, Gender Equality, UN Peacekeeping Operations, Energy Governance. ${ }^{11}$ The key strength of the group that can be operationalised to meet its objectives associate with its material capabilities mentioned in the mission statement of the group. They are democracies that can take advantage of being open economies with robust economic growth rates and are strategically situated and strongly connected to their surrounding areas in all extents. ${ }^{12}$

MIKTA members are important economic powers and play pivotal strategic roles and substantially affect their respective regions. In 2019, the combined GDP of MIKTA countries 6.1 trillion equalled approximately 7.3\% per cent of the global GDP. All of them constitute a quarter of the biggest economy in the world within the G20. They range between the world's twelfth to nineteenth largest economies in terms of GDP, and they can raise their rankings in the future as they are growing at a faster rate than many in the top 10. For instance, Goldman Sachs has foreseen that Mexico may become the 5th largest economy by 2050, and a PWC report predicted that if current growth rates are continuing, Indonesia will be the 7th largest economy by 2030, and 4th by 2050; Turkey may rank among the top 10 as well as Australia and Korea. ${ }^{13}$

MIKTA countries totalise population 553 million that equals approximately $7.3 \%$ of the world's population as of 2019. Their population structures differ significantly, a determinant which will always influence each country's course of the economy. Indonesia is the most populous country among MIKTA countries and ranks 5th globally with a population of 270.3 million. Mexico has a population of almost 130 million; South Korea has a population of nearly 52 million, and Turkey has a population of 83 million. Australia is the fifth country with a total population of 25 million among MIKTA countries.

11 MIKTA, New Innovation Partnership, p. 7-8, in http://www.mikta.org/web/viewer. html?file=/images /2020\%20MIKTA\%20Booklet.pdf (Accessed on 06.06.2020).

12 MIKTA Foreign Ministers, MIKTA Vision Statement, in http://www.mikta.org/about /vision.php (Accessed on 10.12.2020).

13 Julia Bishop, Address to MIKTA outreach event, 2015, in https://www.foreignminister.gov.au/minister/julie-bishop/speech/address-miktaoutreach-event (Accessed on 06.06.2020). 
As mentioned, MIKTA has its origins in the G20. Still, the five-member states do not only belong to G20, but they are also members of many other important international organisations, like the United Nations (UN), the International Monetary Fund (IMF), the World Trade Organization (WTO), the World Bank (WB), and the OECD excluding Indonesia who will join sooner. Only Turkey belongs to the North Atlantic Treaty Organization (NATO) in the group. It must be highlighted at this point that five MIKTA countries have had nonpermanent membership in the UN Security Council in the last decade. Their presence in such bodies indicates that MIKTA members have found the opportunity to cooperate with these multilateral organisations and have a voice in the decision-making procedures. ${ }^{14}$

The MIKTA members have different features and characteristics and are geographically far from each other. Australia lies between the Pacific and Indian oceans. Mexico is positioned between North and South America; Turkey is a bridge between Europe and Asia; Indonesia is a portal to South-East Asia's hotbed, and South Korea is situated between China and Japan..$^{15}$ Cooper states that MIKTA is located in a large territory, including the Asia Pacific, the Middle East, and the Americas. ${ }^{16}$ With this diverse geographical reach, MIKTA countries have the chance to engage actively in chosen niche areas in distinct geographies. ${ }^{17}$

MIKTA states exemplify a multi-cultural character in terms of language, culture, and tradition as well. Indonesia and Turkey are members of the Organisation of Islamic Cooperation and possess a predominantly Muslim social structure. Australia is widely regarded as Protestant, and Mexico has mainly Catholic population. Buddhism and Christianity are supposed to be prevalent in South Korea. Despite all these differences, they are consolidating democratic processes, and they are all free-market economies and conform the rules for fair global governance. ${ }^{18}$

${ }^{14}$ Emel Parlar Dal, Ali Murat Kurşun, Assessing Turkey's middle power foreign policy in MIKTA: Goals, means, and impact. "International Journal”, Vol. 71, 2016, No.4, p. 614. 15 Gilbert Rozman, The Sino-U.S. National Identity Gap, Australia, and the Formation of an Asia-Pacific Community. "Asian Survey”, Vol. 54, 2014, No. 2, p. 364; Antonio Missiroli and Domhnall O'Sullivan, BRICS - the next layer, "European Union Institute for Security Studies", 2013, Vol. 38, p. 2, in https://www.iss.europa.eu/sites/default/files/EUISS Files/Alert_38_Next_BRICS.pdf , (Accessed on 19.05.2020).

${ }^{16}$ Andrew Fenton Cooper, MIKTA and the global projection of middle powers: Toward a summit of their own?, "Global Summitry", Vol. 1, 2015, No. 1, p.109.

17 Emel Parlar Dal, Ali Murat Kurşun, op. cit., p. 614.

18 Fahamu Networks for Social Justice. MIKTA: A global vision of middle powers, in 
Although MIKTA members are entirely different from each other in terms of histories, contexts, demands, potentials and futures, ${ }^{19}$ there are remarkable similarities in such a diverse grouping. They can still hold similar views underlining their common traits. Their political and diplomatic wishes and the similar perspectives that collaborating with other like-minded nations is the best bet to stand for their interests and influence critical global issues to increase their posture. ${ }^{20}$

\section{ANALYSING MIKTA COUNTRIES MIDDLE POWER ROLES (2009-2019)}

\subsection{Material Capabilities Dimension}

To understand better this group, the central common features and key differences will be analysed regarding economic potentials, international trade, and some soft power indicators. The required data will be derived from the World Bank, the United Nations and OECD datasets. As it is challenging to keep track of all available statistics, following economic dimensions will be used for analysing the comparative performances of MIKTA countries:

- Economic Growth

- GDP

- GDP per capita

- Inflation Rate

- Unemployment Rate

- International Trade (Imports and Exports)

- Foreign Direct Investment (FDI)

- General Government Net Debt

- Human Development Index (HDI)

While these properties include economic dimensions of MIKTA countries, they manifest the systemic and domestic structures too.

\subsubsection{GDP of the MIKTA Countries}

The MIKTA members have been called "rising middle powers" as they are

http://www.fahamu.org/ep_articles/mikta-a-global-vision-of-middle-powers/, (Accessed on 07.06.2020).

${ }^{19}$ Ramesh Thakur, How Representative are BRICS?, "Third World Quarterly", Vol. 35, 2014, No. 10, pp. 1791-1808.

${ }^{20}$ Belma Engin, Gürol Baba, MIKTA: A Functioning Product of "New" Middle Power-ism?,

"Review of International Law \& Politics", Vol. 11, 2015, No. 42, p. 30. 
not equal to the developed and biggest economies of the G7, but are remarkably more advanced than the developing countries. ${ }^{21}$ South Korea is the 12th largest economy in the G20 and ranked 4th in Asia with a nominal GDP of \$1.64 trillion in 2019. The South-Korean society was among the world's poorest countries, but it has shown a spectacular rise and became a high-income country. Considering its small geographical area, scarce natural resources, and population size, South Korea has given particular importance to technological progress and innovation to ensure growth and become a hi-tech, an urban and industrialised country. ${ }^{22}$ In terms of GDP per capita, with a value of 31846 U.S. dollars in 2019 above the world average (15222.64 U.S. dollars), South Korea ranked 31st among 176 countries.

Mexico is the second-largest economy in Latin America. It ranks 15th largest economy on the global map with a nominal GDP of 1268 billion US dollars as of 2019 and abundant natural resources. With GDP per capita of 9946 current US dollars, the country ranked 67th in 2019. Australia, the world's one of the significant energy and food exporters, is the 14th-biggest economy with a value of 1396 billion US dollars in terms of GDP. However, it is the wealthiest nation of Southeast Asia with a GDP per capita of 55060 US dollars as of 2019, and it achieved on average and ranked 11th in the world. Indonesia has a nominal GDP of 1.11 trillion. The country ranks 16 th globally and is the largest economy in Southeast Asia and is the biggest economy in Southeast Asia. Although Indonesia suffered enormously from the 1997 Asian fiscal crisis, its economy has shown impressive growth over the last two decades. For GDP per capita, the value for Indonesia in 2019 is 4135 U.S. dollars. For comparison, among 176 countries, the country ranked 108th in 2019. Turkey is the world's 19 th largest economy with its $\$ 761$ billion GDP. Concerning GDP per capita, the latest value of 2019 is 9126 U.S. dollars, putting the country on the 70th position among 176 countries.

${ }^{21}$ Gordon Flake, Xu Wang, MIKTA: The Search for a Strategic Rationale, 2017, p. 8, in https://perthusasia.edu.au/getattachment/Our-Work/MIKTA-The-Search-For-AStrategic-Rationale/MIKTA-report-June-2017.pdf.aspx?lang=en-AU (Accessed on 06.06.2020).

22 Nordea Trade Portal, South Korea: Economic and Political Overview, in https://www.nordeatrade.com/fi/explore-new-market/south-korea/economicalcontext (Accessed on 12.06.2020). 
Table 1: GDP of the MIKTA Countries in 2009-201923

\begin{tabular}{|l|c|c|c|c|c|c|c|}
\hline \multirow{2}{*}{ Country } & \multirow{2}{*}{$\begin{array}{c}\text { Rank in } \\
\text { World 2019 }\end{array}$} & \multicolumn{2}{|c|}{$\begin{array}{c}\text { GDP (current } \\
\text { price); } \\
\text { billion }\end{array}$} & \multicolumn{2}{c|}{$\begin{array}{c}\text { Share in } \\
\text { World GDP } \\
\text { (\%) }\end{array}$} & \multicolumn{2}{c|}{$\begin{array}{c}\text { GDP per } \\
\text { capita (\$) }\end{array}$} \\
\cline { 3 - 8 } & $\mathbf{2 0 0 9}$ & $\mathbf{2 0 1 9}$ & $\mathbf{2 0 0 9}$ & $\mathbf{2 0 1 9}$ & $\mathbf{2 0 0 9}$ & $\mathbf{2 0 1 9}$ \\
\hline Mexico & 15 & 900 & 1268 & 1.49 & 1.44 & 8003 & 9946 \\
\hline Indonesia & 16 & 539 & 1119 & 0.90 & 1.23 & 2261 & 4135 \\
\hline Korea, Rep. & 12 & 943 & 1646 & 1.57 & 2.02 & 19143 & 31846 \\
\hline Turkey & 19 & 649 & 761 & 1.07 & 0.91 & 9103 & 9126 \\
\hline Australia & 14 & 927 & 1396 & 1.54 & 1.69 & 42772 & 55060 \\
\hline Total & -- & 3.958 & 6.190 & 6,57 & 7.29 & -- & -- \\
\hline
\end{tabular}

\subsubsection{GDP Growth Rate}

The MIKTA countries have experienced relatively fast GDP growth for over a decade. While most of the world countries were in the grip of the global financial crisis in 2009, three of the MIKTA members, Australia, Korea, and Indonesia were able to achieve growth. On the other hand, the crisis deeply affected Mexico and Turkey, but they made significant progress in the following years. During the global financial crisis in 2008, South Korea sustained a stable economy and even experienced an economic boost at the peak of the generalised decline. However, the country could not achieve its growth rates before the global financial crisis. The government managed the problem well and showed the fastest recovery among OECD members. ${ }^{24}$ Mexico has underperformed in terms of growth, compared to similar countries over the last three decades. In 2019, Mexico growth rate was $-0.15 \%$, a $2.28 \%$ decline from 2018 . The Australian economy grew by 2.2\% between 2018-19. Indonesia's economic growth averaged 5.4 per cent a year, and the latest value in 2019 is 5\%. Between 2009 and 2019, Turkey's annual economic growth averaged $4.9 \%$. In 2019 , the economy registered a $0.9 \%$ growth

23 The World Bank, World Development Indicators, in https://databank.worldbank.org/ source/world-development-indicators (Accessed on 12.06.2020).

24 Jong-Wha Lee, The Republic of Korea's Economic Growth and Catch-Up: Implications for the People's Republic of China. ADBI Working Paper, 2016, No. 571, in https://www.adb.org/sites/default/files/publication/183353/adbi-wp571.pdf (Accessed on 15.05.2020). 
below the world average. However, Turkey is predicted to participate with the trillion-dollar club as of 2023.

Economic performances of the MIKTA countries differ as Indonesia, Australia, and Korea have steady growth rates while Mexico and Turkey's growth seem to be mainly unstable. However, the gap and difference between growth rates of MIKTA countries have begun to decimate recently.

\subsection{0}

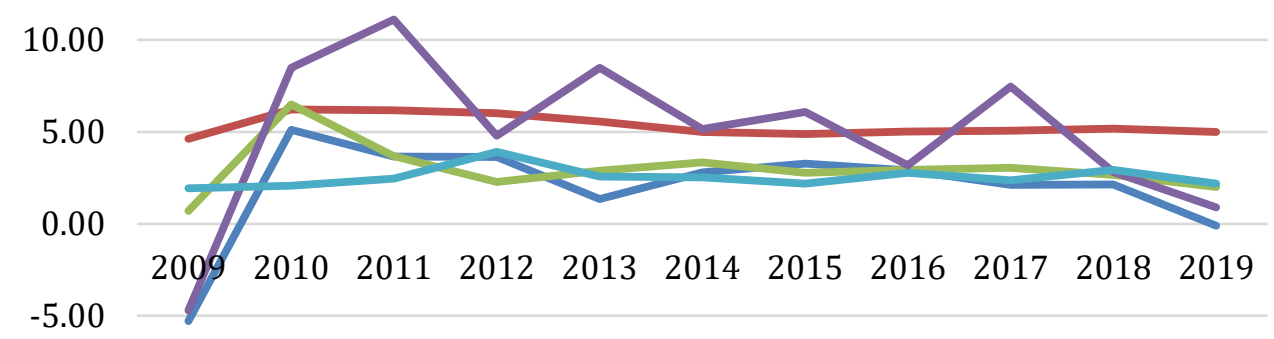

$-10.00$

$\longrightarrow$ Mexico Indonesia $\longrightarrow$ Korea, Rep. —Turkey $\longrightarrow$ Australia

Figure 1. GDP Growth Rates (\%) of MIKTA Countries in 2009-201925

\subsubsection{Inflation}

One main difference among the MIKTA economies is that Turkey and Indonesia have comparatively high inflation (consumer prices) during the given period. However, Indonesia achieved relatively low levels of inflation rates since 2015. In 2019, the annualised inflation rate in the country was $3 \%$. Turkey released the highest inflation rate, with $16.3 \%$ in 2018. The latest value for Turkey, in 2019, is 15.2\%. Mexico inflation rate for 2019 was 3.64\%.

The inflation in Korea climbed 1.5 per cent in 2018, that is the third-year inflation has hovered in the 1 per cent range. The latest value in 2019 is $0.4 \%$. Considering the average for that indicator in 2019 based on 149 countries was 3.8 per cent, and South Korea's value below the government estimate of 1.6 per cent and the central bank's target of around 2.0 per cent, the country is efficacious in maintaining low levels of inflation. Inflation in Australia was reported at $1.6 \%$ in

25 The World Bank, World Development Indicators, in https://databank.worldbank.org/ source/world-development-indicators (Accessed on 12.06.2020). 
2019. Although Australia's inflation rate fluctuated substantially in recent years, it tended to decrease through the 2000s.

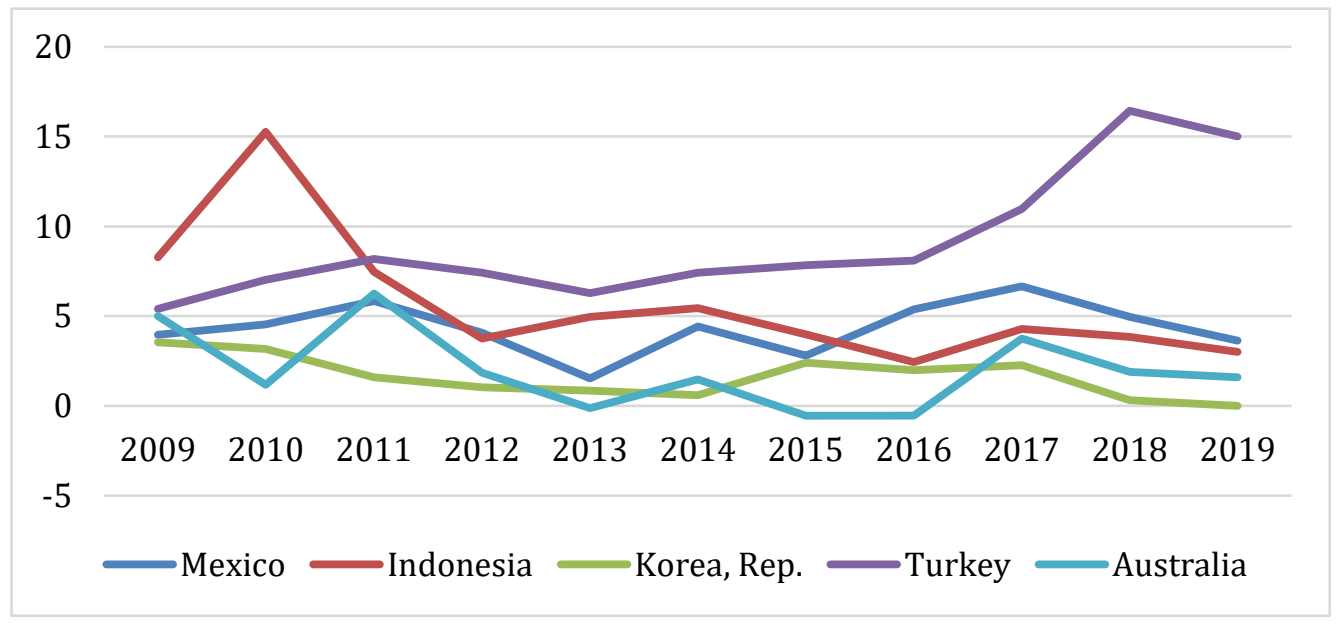

Figure 2. Inflations of MIKTA Countries in 2009-201926

\subsubsection{Unemployment}

In 2009, when the global financial crisis reached its peak, Turkey, Australia, and Mexico encountered growing unemployment rates. Even though Turkey's unemployment rate has begun to recede below its pre-crisis level, the country has got to fight against relatively high inflation, as it was at a level of $13 \%$ in 2019 . The unemployment rate in Indonesia has continued to decline, even during the time of the crisis. South Korea's average unemployment rate has been remaining at a level of $3 \%$. The country's unemployment rate in 2019 was $4.15 \%$. Given the average in 2018 based on 182 countries was 7.07 per cent, the unemployment rate was low in the country that ranked 128th. The unemployment rate in Mexico was accounted for 3.42\% in 2019, slightly upper from the rate in 2018 (3.28\%). Australia recorded a 5\% unemployment rate in 2019. The unemployment rate in Indonesia was $4.69 \%$.

\subsubsection{International Trade}

International trade is a significant factor for the economies of the MIKTA countries as they all are important traders in the world. Nevertheless, the structure and management of trade among MIKTA countries are different. Australia and Indonesia mainly export agricultural products. Korea and Mexico import

26 Ibid. 


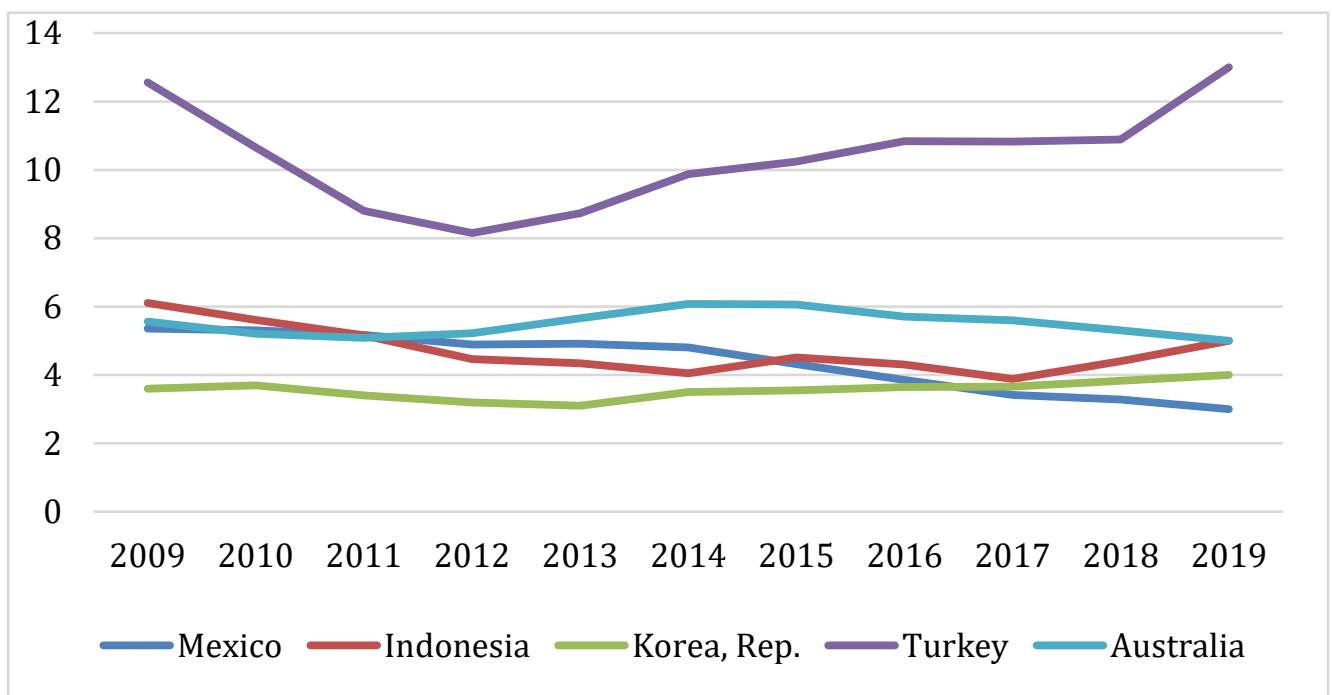

Figure 3. Unemployment Rates of MIKTA Countries in 2009-2019 (\% of Total Labour Force) $)^{27}$

farming goods. Korea and Turkey import fuels, minerals, and commodities while Australia is a crucial exporter of them. Korea and Mexico exports also manufactured goods. South Korea is among the world's top ten importers and exporters. The country imported 542 billion US\$ worth of goods and services in 2019 and shipped 503 billion US\$ worth of goods around the globe. The import of Mexico in goods and services from around the world is valued at US\$460 billion as of 2019. The United States purchased nearly half (44.1\%) of Mexico's total imports by value in 2019. On the other hand, Mexico exported US $\$ 467$ billion worth of goods and services. The top three export destinations of Mexico are the United States, Canada, and China. On the other hand, as Mexico is a key exporter of oil, it is a market open to the world. Australia shipped an overall US $\$ 270$ billion worth of goods around the world as of $2019.67 .9 \%$ of products exported from Australia were bought by importers in China (38.7\% of the global total), Japan, Republic of Korea, the United Kingdom, and the United States. Australia's imports totalled US $\$ 221$ billion in 2019 . Indonesia shipped US $\$ 167$ billion worth of goods around the globe, and the country's imports totalled US\$170 billion in 2019 . Turkey's exports of goods and services accounted for US $\$ 180$ billion, and its imports of goods valued at US\$210billion in 2019.

Trade openness measured by the sum of imports and exports as a percentage of GDP indicates that all MIKTA members are open economies with the values

27 Ibid. 
ranging from Indonesia's 37.30\% to Mexico's 78.18\%. Compared to 2009, the relative trade openness of only Turkish and Mexican economies has increased. In 2019, Mexico and Indonesia reported trade deficits. On the other hand, Mexico, Indonesia, and Australia managed to retain generally balanced commercial patterns despite small trade deficits considering their current account balance ratio to GDP. Although Turkey's trade deficit is at the bottom of the heap, there is no significant difference from the others in a broader international context.

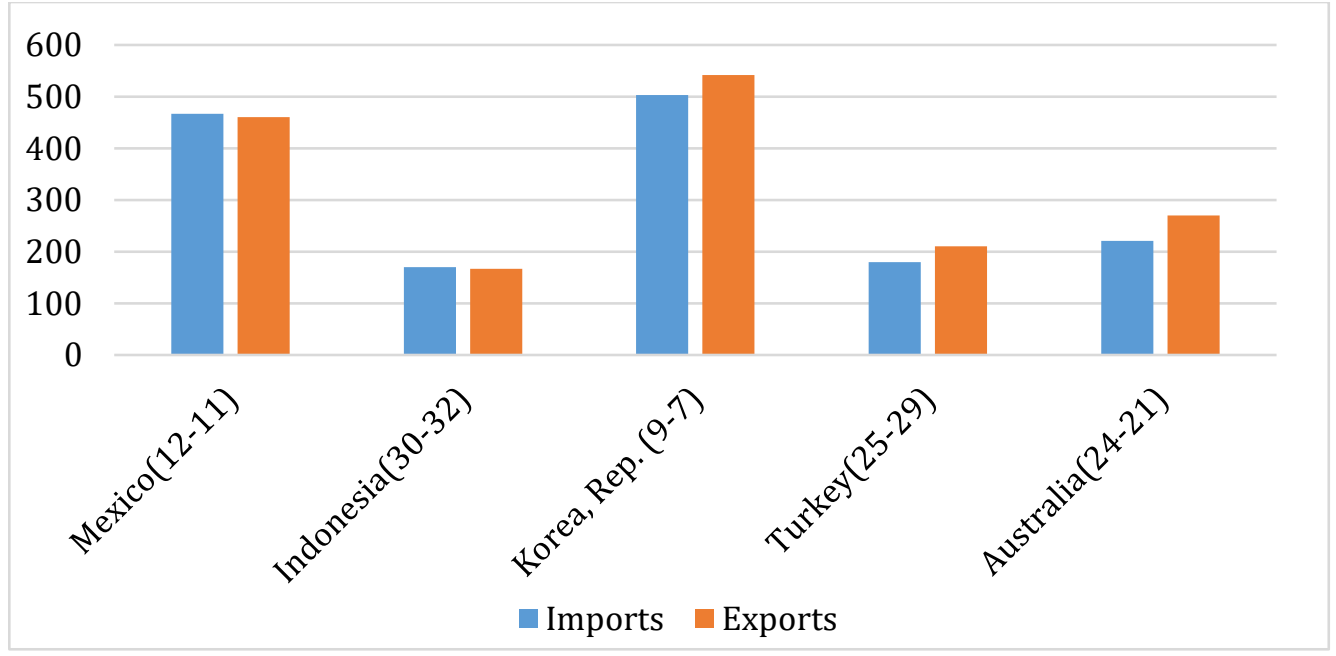

Figure 4. Imports and Exports of Goods and Services (Billion USD, 2019; World Rank /Import-Export/28

Table 2. Trade of MIKTA Countries (\% of GDP, 2009-2019)29

\begin{tabular}{|c|c|c|c|c|c|c|c|c|}
\hline \multirow{2}{*}{ Country } & \multicolumn{2}{|c|}{ Exports } & \multicolumn{2}{c|}{ Imports } & \multicolumn{2}{c|}{$\begin{array}{c}\text { Current Account } \\
\text { Balance }\end{array}$} & \multicolumn{2}{c|}{$\begin{array}{c}\text { Trade } \\
\text { Openness }\end{array}$} \\
\cline { 2 - 9 } & $\mathbf{2 0 0 9}$ & $\mathbf{2 0 1 9}$ & $\mathbf{2 0 0 9}$ & $\mathbf{2 0 1 9}$ & $\mathbf{2 0 0 9}$ & $\mathbf{2 0 1 9}$ & $\mathbf{2 0 0 9}$ & $\mathbf{2 0 1 9}$ \\
\hline Mexico & 27.15 & 39.3 & 28.81 & 39.11 & -0.87 & -0.19 & 55.97 & 78.18 \\
\hline Indonesia & 24,16 & 21.0 & 21.35 & 18.90 & 1.97 & -2.72 & 45.51 & 37.30 \\
\hline Korea & 48.19 & 44.0 & 40,95 & 36.88 & 3.51 & 3.65 & 86.13 & 76.71 \\
\hline Turkey & 22.57 & 31.61 & 23.36 & 29.78 & -1.76 & 1.15 & 45.93 & 61.39 \\
\hline Australia & 23 & 24.13 & 22.79 & 21.56 & -5.27 & 0.51 & 45.80 & 45.69 \\
\hline
\end{tabular}

${ }^{28}$ WTO (World Trade Organization), World Commodity Profiles. 2019, in https://www.wto.org/english/res_e/statis_e/trade_profiles_list_e.htm (Accessed on 06.06.2020). ${ }^{29}$ Ibid. 
Table 3. Trade Partners of MIKTA Countries, 201930

\begin{tabular}{|c|c|c|c|c|}
\hline Country & $\begin{array}{l}\text { Major export } \\
\text { destinations }\end{array}$ & $\begin{array}{c}\text { Share in total } \\
\text { import (\%) }\end{array}$ & $\begin{array}{l}\text { Major import } \\
\text { sources }\end{array}$ & $\begin{array}{c}\text { Share in total } \\
\text { export (\%) }\end{array}$ \\
\hline \multirow{3}{*}{ Mexico } & United States & 76.1 & United States & 44.1 \\
\hline & EU & 3.5 & China & 17.8 \\
\hline & Canada & 3 & EU & 10.4 \\
\hline \multirow{3}{*}{ Indonesia } & China & 16.7 & China & 26.3 \\
\hline & United States & 10.6 & Singapore & 10.1 \\
\hline & Japan & 9.5 & Japan & 9.1 \\
\hline \multirow{3}{*}{ South Korea } & China & 25.1 & China & 21.3 \\
\hline & United States & 13.6 & United States & 12.3 \\
\hline & Vietnam & 8.9 & EU & 10.3 \\
\hline \multirow{3}{*}{ Turkey } & EU & 43.1 & EU & 32.4 \\
\hline & $\begin{array}{c}\text { United } \\
\text { Kingdom }\end{array}$ & 6.2 & $\begin{array}{c}\text { Russian } \\
\text { Federation }\end{array}$ & 11 \\
\hline & Iraq & 5.6 & China & 9.1 \\
\hline \multirow{3}{*}{ Australia } & China & 38.7 & China & 23.8 \\
\hline & Japan & 14.8 & EU & 15.9 \\
\hline & South Korea & 6.6 & United States & 11.9 \\
\hline
\end{tabular}

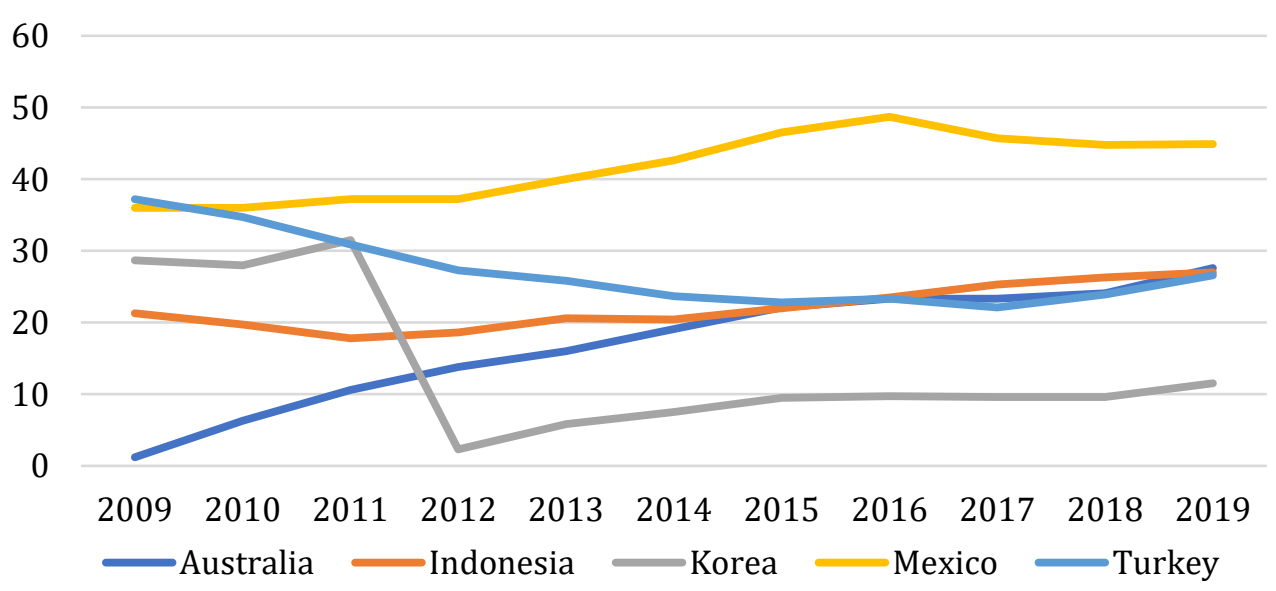

Figure 5. General Government Net Debt of MIKTA Countries

(\% of GDP, $2009-2019)^{31}$

${ }^{30} \mathrm{Ibid}$.

31 IMF, World World Economic Outlook Database, in https://www.imf.org/en/Publications/WEO/weo-database/2020/October/weo- 


\subsubsection{Deficit and Debt Sustainability}

Figure 5 shows the general government's net debt (\% of GDP) of MIKTA countries. In 2019, general government net debt for Korea was 11.5\%; Turkey 26.6\%; Indonesia 27\%; Australia 27.6 \% and Mexico 44,9\%. The debt ratio for Turkey has been on the decline for the given period. The debt ratio of Mexico, Korea and Indonesia are increasing at a slow rate. The general debt condition of MIKTA countries can be described as steady in general.

\subsubsection{Foreign Direct Investments}

FDI in developing economies has been instrumental in contributing to the overall economic growth of a country. Therefore, nations struggle to fulfil the conditions to encourage more FDI inflows into their economies. ${ }^{32}$

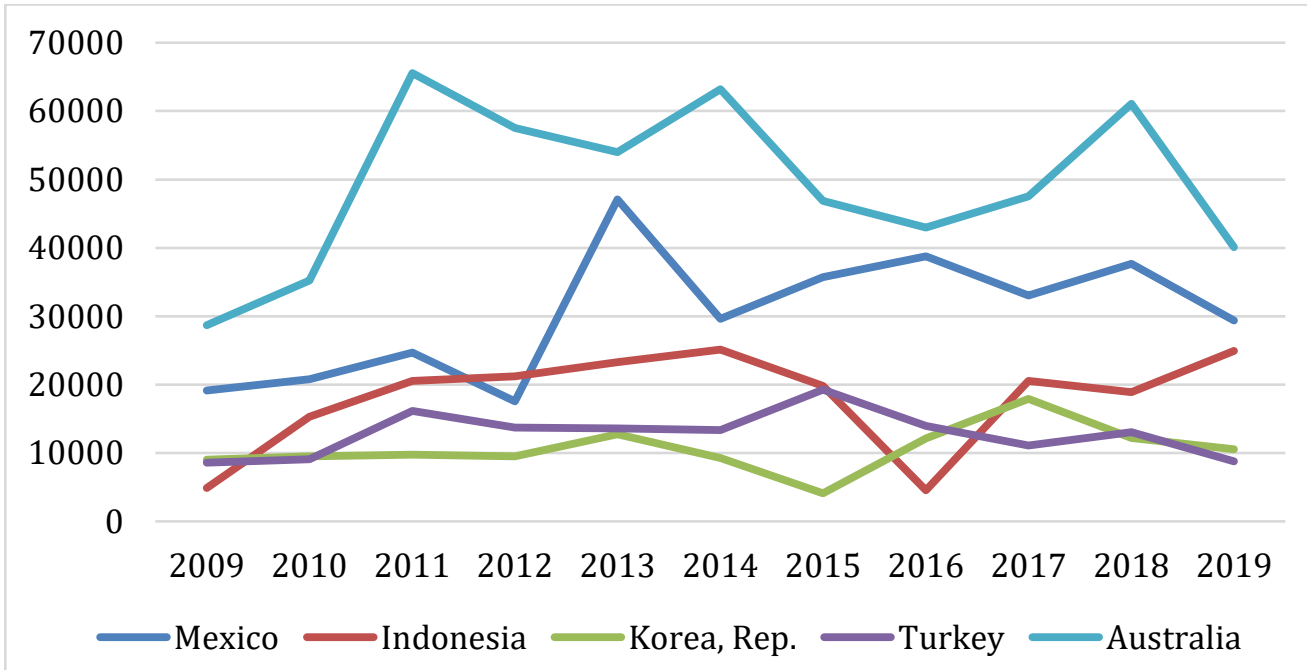

Figure 6. Foreign Direct Investment, Net Inflows (BoP, Current US\$, Millions) ${ }^{33}$

Net FDI inflows for South Korea was 10566 million US dollars in 2019. Though South Korea's net FDI inflows fluctuated considerably in recent years, it tended to increase through the 2000s. The country was the 29th recipient of FDI

report?c=193,536,542,273,186,\&s=GGXWDN_NGDP,\&sy=2009\&ey=2019\&ssm=0\&scs $\mathrm{m}=1 \& \mathrm{scc}=0 \& \mathrm{ssd}=1 \& \mathrm{ssc}=0 \& \mathrm{sic}=0 \& \mathrm{sort}=$ country\&ds=.\&br=1 (Accessed on 20.12.2020).

32 Provi Jadhav, Determinants of foreign direct investment in BRICS economies: Analysis of economic, institutional and political factor, "Procedia - Social and Behavioural Sciences", 2012, No. 37, p. 6.

33 The World Bank, World Development Indicators, in https://databank.worldbank.org/ source/world-development-indicators (Accessed on 12.06.2020). 
inflows in the world in 2019. Mexico is the world's 15th largest FDI recipient. In 2019, FDI inflows for the country was 29360 million US dollars. While flows remained comparable to levels seen in the given period, they were substantially below the all-time high of USD 47195 million in 2013. For that indicator, Australia ranked 10th with a value of 40075 million U.S. dollars in 2019. Indonesia ranked 17 th with a value of 24947 million US dollars in 2019. Turkey ranked 34th with a value of 87870 million US dollars in 2019.

\subsubsection{Human Development Index (HDI)}

HDI, which combines social and economic indicators, is also utilised as evaluation criteria of MIKTA countries. Australia is the most developed country in terms of HDI among MIKTA grouping with a score of 0,944 . The country ranked 8th in HDI world rank among very high human development category. South Korea also shows very high human development ranking 23rd among in 2019 with a score of 0,916. Mexico ranked 74th with a score of 0,779 in the high human development category. Indonesia's HDI value is 0.718 , positioning it at 107 and Turkey ranked 54th with the HDI value of 0,820 in 2019.

Table 4. Human Development Index of MIKTA Countries, 2009-201934

\begin{tabular}{|c|c|c|c|c|}
\hline \multirow{2}{*}{ Country } & \multicolumn{2}{|c|}{2009} & \multicolumn{2}{c|}{2019} \\
\cline { 2 - 5 } & HDI & Rank & HDI & Rank \\
\hline Mexico & 0.745 & 56 & 0.779 & 74 \\
\hline Indonesia & 0.593 & 108 & 0.718 & 107 \\
\hline South Korea & 0.872 & 12 & 0.916 & 23 \\
\hline Turkey & 0.674 & 83 & 0.820 & 54 \\
\hline Australia & 0.935 & 2 & 0.944 & 8 \\
\hline
\end{tabular}

MIKTA countries are relatively similar to each other concerning their comparative hard and soft power performance. Table 5 represents a summary of all selected variables ( $\uparrow$ highest value and $\downarrow$ minimum value) mentioned above, according to their average scores during 2009-2019. Although

${ }^{34}$ United Nations Development Programme, Human Development Report 2020, The next frontier Human development and the Anthropocene, in http://hdr.undp.org/sites/ default/files/hdr2020.pdf (Accessed on 21.12.2020); United Nations Development Programme, Human Development Report 2010, The Real Wealth of Nations: Pathways to Human Development, in http://hdr.undp.org/sites/default/files/reports/270/ hdr_2010_en_complete_reprint.pdf (Accessed on 21.12.2020). 
Indonesia has the highest growth rate among MIKTA countries, it ranks 5th in terms of GDP per capita, which describes the standard of living of a population and shows its economic performance and strength. Turkey has the highest unemployment and inflation rates, which are among the most serious macroeconomic problems. Turkey is also at the top in terms of imports and general government debt. While Australia is the first country which encourages foreign direct investment, Turkey ranks 5th among MIKTA countries. As the study suggests, MIKTA countries together represent an intermediate position. More specifically, Australia and South Korea have a high profile, whereas Indonesia and Mexico show worse performance even they tend to increase their hard and soft power capacities.

For Turkey, these indicators put the country into a "middle position" among MIKTA grouping. In line with Turkey's objective to raise its international status, in 2011, the Justice and Development Party government issued 2023 vision document of the country. This strategy was expressing Turkey's aim "to be among the top economies of the world in terms of the GDP, to maintain a stable reduction in inflation and keep interest rates to a single digit, to increase exports to 500 billion dollars per year, to increase per capita income to $\$ 25,000$, to reach annual GDP of 2 trillion dollars, to reduce the unemployment rate to $5 \%$, and to increase the present employment rate to at least 50\%." 35 In the light of Turkey's low profile and poor performance in key economic indicators, it needs to increase research and development expenditures and decrease high consumption rates and energy dependency of the country, resulting in a reduction in the country's massive imports. All of these may positively affect the general government debt and current account deficit and may even contribute to a decrease in inflation caused by reductions in costs. So, Turkey can obtain a more robust profile and rate among more developed and prestigious groupings of the world. Based on its role in MIKTA, Turkey has had the opportunity to acquire a more exact point of view, identifying those countries its performance can be compared with, and what aims it can hold practicable in economic development and global issues governance. ${ }^{36}$

35 AK Party, Political Vision of AK Party 2023: Politics, Society and the World, in https://www.akparti.org.tr/parti/2023-siyasi-vizyon/ (Accessed on 21.11.2020).

${ }^{36}$ Selcuk Colakoglu, The Role of MIKTA in Global Governance: Assessments \& Shortcomings, p. 281. 
Table 5. Evaluation of MIKTA's material and soft power indicators (average value of 2009-2019)

\begin{tabular}{|c|c|c|c|c|c|}
\hline $\begin{array}{c}\text { Country/ } \\
\text { Indicators }\end{array}$ & Mexico & Indonesia & Korea & Turkey & Australia \\
\hline GDP growth & $\downarrow$ & $\uparrow$ & & & \\
\hline GDP & & & & $\downarrow$ & $\uparrow$ \\
\hline GDP per capita & & $\downarrow$ & & & $\uparrow$ \\
\hline Inflation & & & $\downarrow$ & $\uparrow$ & \\
\hline Unemployment & & & $\downarrow$ & $\uparrow$ & \\
\hline Exports & & & $\uparrow$ & & $\downarrow$ \\
\hline Imports & & & $\uparrow$ & & $\downarrow$ \\
\hline General & $\uparrow$ & & & & $\uparrow$ \\
\hline government debt & & & & & $\uparrow$ \\
\hline FDI & & & $\downarrow$ & & \\
\hline HDI & & $\downarrow$ & & & \\
\hline
\end{tabular}

\subsection{Behavioural Factors: Effectiveness, Challenges and Prospects of MIKTA}

It is emphasised that middle powers' material capacities are significant for global governance and what they do and achieves with these capacities are also noteworthy. To make it clear, middle powers tend to pursue multilateral solutions to international debates; favour coalition building, and adopt good international citizenship notions to conduct diplomacy. ${ }^{37}$ Within this context, it must be underlined that MIKTA grouping enabled middle powers to increase their voice higher on the need to reform the United Nations and multilateral institutions and played significant roles in serving as a bridge between developed and developing nations in the G20 sessions. ${ }^{38}$

Middle powers also give weight to niche diplomacy, which implies concentrating resources in specific fields ${ }^{39}$ to scale up their capacity and status and gain a competitive advantage in global politics. In the case of MIKTA, Australia

37 Gareth Evans, Middle Power Diplomacy, Lecture in Chile Pacific Foundation, Santiago, 2011, in http://www.gevans.org/speeches/speech441.html (Accessed on 21.12.2020).

${ }^{38}$ Radiye Funda Karadeniz, The Middle Power Moment' Revisited in Global Governance: A

Chance for MIKTA's Legitimacy Crisis in Post-Pandemic World?, "Marmara University Journal of Political Science", Vol. 8, 2020, Special Issues, p. 26.

${ }^{39}$ Gareth Evans, op. cit. 
is a crucial example for niche diplomacy in the realms of human rights, environmental goals and leadership on non-proliferation; Korea has concentrated on settling research and development capabilities and technology transfer to contribute to other MIKTA members and on a larger scale. ${ }^{40}$ In the same manner, Mexico has invested in global environmental politics, and Turkey has achieved great success in humanitarian diplomacy.

Before the MIKTA's establishment, five countries set their political aims based on their priorities or the allies' and partners' objectives. Although they are instrumental in shaping global policy processes within the G20, their efforts were brought into disrepute, many times, by the G7 and BRICS groups. As they are named as "second-tier" countries within the body of the G20, they have been unable to wield their influence in global governance. For this reason, the foundation of MIKTA has enhanced its members' activism in the G20. The five MIKTA members expend energy on reducing their differences and maximising their commonalities and internal harmony.41 Since the creation of MIKTA, various global and regional issues have become the focus of its agenda. However, there is a degree of uncertainty and confusion about what MIKTA has been achieved or solved so far.

MIKTA is a group that is already in progress. Some analysts alleged that MIKTA is "a waste of time" 42 and "its only success may be that it still exists" 43 The MIKTA group is not being considered as a prestigious and leading model of global governance for middle powers because of their internal political problems turning their attention away from the institutional empowerment of cooperation throughout this informal grouping. ${ }^{44}$ Concerning the volume, the group has

${ }^{40}$ Ziya Öniş, Mustafa Kutlay, The dynamics of emerging middle-power influence in regional and global governance: the paradoxical case of Turkey, "Australian Journal of International Affairs", Vol. 71, 2017, No. 2, p. 169.

${ }^{41}$ Selçuk Çolakoğlu, Has MIKTA augmented the global governance role of middle powers? "The Global", 2018, in https://theglobal.blog/2018/05/29/has-mikta-augmented-theglobal-governance-role-of-middle-powers (Accessed on 12.12.2020).

42 Jeffrey Robertson, Where next for MIKTA?, "The Interpreter", 2020, in https://www.lowyinstitute.org/the-interpreter/where-next-mikta (Accessed on 12.12.2020).

43 Jeffrey Robertson, South Korea's quandary: What to do about MIKTA?, "The Interpreter", 2018, in https://www.lowyinstitute.org/the-interpreter/south-korea-quandarywhat-do-about-mikta (Accessed on 20.12.2020).

${ }^{44}$ Gonca Oğuz Gök, Radiye Funda Karadeniz, Emerging Middle Powers in Global Political Economy: Preferences, Capabilities and their Limitations, in Dal Emel Parlar (eds), 
undoubtedly achieved as much as any other informal unit. ${ }^{45}$ However, MIKTA could not be identified just based on economic ranking and material capabilities. There is also a fundamental political factor that is moving beyond immediate neighbour. The MIKTA members are far more constrained in showing such an approach. ${ }^{46}$ However, it must be underlined that there are symbolic and material barriers related to local issues for MIKTA members to go global. ${ }^{47}$ For instance, while Mexico has carried out various policies considering migration, Turkey is concerned with security-related matters and refugees. As a senior member of ASEAN, Indonesia tries to build and redefine the community's values. Australia is experienced in balancing China and the United States' relationship, while South Korea is dealing with peninsular issues. ${ }^{48}$

MIKTA's heterogeneity reveals both its strengths and weaknesses. Although MIKTA attracts each of its members for several reasons, their own political and economic interests vary from country to country. They also adopt diverse attitudes toward current order - ranging from revisionist in Turkey's case to status-quo in Australia's case. As it is mentioned, five MIKTA members followed a vision statement and specified seven priority issues they differ in how they interpret and how they are eager to reach these purposes. ${ }^{49}$ Because all members of MIKTA had to focus primarily on their domestic political or economic issues, they did not have enough energy and time to deal with global governance issues. For example, 2016 and 2017 were considered missing two consecutive years for the sustainability of MIKTA because of the internal process of establishing the programme of five Member States and national policy concerns. ${ }^{50}$ In 2010, six premiers succeeded one another in Australia. Turkey had to clash

Turkey's Political Economy in the 21st Century. International Political Economy Series. Palgrave Macmillan, 2020, p. 163-194.

45 Jeffrey Robertson, Where next for MIKTA?.

${ }^{46}$ Andrew Fenton Cooper, MIKTA and the Global Projection of Middle Powers: Toward a Summit of Their Own?, "Global Summitry", Vol. 1, 2015, Issue 1, p. 107.

47 Ibid, p. 109.

${ }^{48}$ Selcuk Colakoglu, The Role of MIKTA in Global Governance: Assessments \& Shortcomings.

"Korea Observer", Vol. 47, 2016, No. 2, p. 277-278.

${ }^{49}$ Stewart M. Patrik, Asley Feng, MIKTA in the Middle: A Little-Known Multilateral Group

Turns Five, 2018, in https://www.cfr.org/blog/mikta-middle-little-knownmultilateral-group-turns-five (Accessed on 18.05.2020).

${ }^{50}$ Selçuk Çolakoğlu, Is MIKTA sustainable as a middle power grouping in global governance?, "Diplo", 2017, in https://www.diplomacy.edu/blog/mikta-sustainablemiddle-power-grouping-global-governance (Accessed on 17.12.2020). 
against the effects of the coup attempt in 2016. The president of South Korea was detained in 2018, while Indonesia and Mexico also had presidency elections. In this respect, it can be said that questions on the legitimacy of MIKTA in world governance have arisen. ${ }^{51}$

The effect of this grouping remains uncertain at the global level. This uncertainty is the result of its lack of subject specificity that makes it challenging to clarify the purpose of the MIKTA. At the beginning of 2020, MIKTA has paid attention to Covid-19. Various challenges associated with COVID-19 must be addressed by global governance. Five MIKTA states shared their respective countries' experiences in coping with the pandemic during its global infection and examined ways to enhance collaboration amid its members in the fields of health and disease prevention.

Reminding that MIKTA is a cross-regional and new innovative partnership, MIKTA Foreign Ministers' Joint Statement on the COVID-19 Pandemic and Global Health stated that MIKTA would continue to play a leading role in promoting global health, protecting public goods, and strengthening global governance. ${ }^{52}$ However, the collaboration of MIKTA states on COVID-19 has raised question marks in minds with the worry of facing unexpected risks for MIKTA bloc, which have already concerned with various issues..$^{33}$ On the other hand, there is an expectation that MIKTA will stand in the breach as countries such as the US, China and Russia are not signing the World Health Organization initiative to provide equitable access to vaccines. ${ }^{54}$ As a result, the battle against COVID-19 may increase MIKTA's global governance role in the future. 55

${ }^{51}$ Radiye Funda Karadeniz, op.cit., p. 29.

52 Republic of Turkey Ministry of Foreign Affairs, MIKTA Foreign Ministers' Joint Statement on the COVID-19 Pandemic and Global Health, 9 April 2020, in http://www.mfa.gov.tr/covid-19-a-iliskin-mikta-bildirisi-hk.en.mfa (Accessed on 18.12.2020).

53 Beginda Pakpahan, Can Indonesia Help MIKTA Thrive? 2018, in https://thediplomat.com/2018/04/can-indonesia-help-mikta-thrive/ (Accessed on 18.12.2020).

54 Maria Siow, Mikta who? Covid-19 injects five 'middle power' countries with new sense of purpose, 2020, in https://www.scmp.com/week-asia/politics/article/3104456/ mikta-who-covid-19-injects-five-middle-power-countries-new-sense (Accessed on 18.12.2020).

55 Stephan Klingebiel, MIKTA: What's in a name? The potential of middle power cooperation to strengthen global governance, 2020, in https://www.undp.org/content/seoul_policy_center/en/home/presscenter/articles/ 
Beyond a doubt, all MIKTA members encounter certain limitations in their potential contribution to strengthening global governance. To meet these constraints, MIKTA needs to construct a more coherent collective identity ${ }^{56}$ and set specific targets that are not necessarily related to general issues of global governance. Moreover, as MIKTA has only held meetings on ministeriallevel mainly during the annual UNGA opening or at the G20, MIKTA draws criticism for being only a talk shop and "staying below the radar" of international debate. Therefore, MIKTA needs to summit at the leader's level.57 Within this background, the extent to which five MIKTA states will succeed in creating a shared vision and strategic position upon their mutual benefits in global governance will shape the MIKTA's future and affect its sustainability as a successful middle power bloc in changing international order.

\section{CONCLUSIONS}

In the 2000s, considered as the information age, countries have made significant changes in their political, social and economic understanding at national and international levels. This transformation led by the developing countries has led to the disintegration of the significant powers system. The practices of Western or developed countries that dominate the world politics and economy through organisations such as the EU, UN, G8, IMF and World Bank have led the developing countries to seek new political and economic cooperations. States that came to the fore in economic progress, especially after the 2008 global financial crisis, seek to strengthen their development within the new structures. Within this context, Mexico, Indonesia, South Korea, Turkey, and Australia have recently made an informal alliance under the acronym of MIKTA.

MIKTA members are all open economies; have robust internal markets; moderate inflation, and grow purchasing power populations. They are building up resilient economies and have the potential for high growth rates, and they are making efforts for accelerating democratic transition processes. They are all "bridge countries" in their respective regions. They aim to league together against regional and international problems and promote stability and welfare by supporting multilateralism and global attempts. They also seek reforms in global

2020/mikta--what_s-in-a-name--the-potential-of-middle-power-cooperati.html

(Accessed on 18.12.2020).

${ }^{56}$ Andrew Fenton Cooper, MIKTA and the Global Projection of Middle Powers..., p. 108.

57 Ibid. 
governance structures. They also have the willingness to develop their new roles and status within the international system.

The main obstacle for MIKTA states to focus on the grouping and therefore, the most significant risk for MIKTA is an economic downturn in its members. As mentioned in the study, they have to struggle with low growth rates and high unemployment numbers, especially in recent times, as they are trying to prevent the spread of Covid 19 pandemic with several precautions. It is seen that the political and economic upheavals lead countries to tackle mostly with their internal politics. Nevertheless, in the political vacuum due to preconized US withdrawal from WHO, middle powers may get more space to affect the future of global health governance with their relatively successful performances and joint initiations during the crisis. However, MIKTA, for the moment, is far from being a prestigious and more leading model of global governance for middle powers as a result of several domestic political and economic problems among its members causing them to lose concentration on the institutional empowerment of cooperation within this informal grouping.

\section{BIBLIOGRAPHY:}

1. AK Party, Political Vision of AK Party 2023: Politics, Society, and the World, in https://www.akparti.org.tr/parti/2023-siyasi-vizyon/

2. Bishop Julie, Address to MIKTA outreach event, 2015, in https://www.foreignminister.gov.au/minister/julie-bishop/speech/address-miktaoutreach-event

3. Çolakoğlu Selçuk, Is MIKTA sustainable as a middle power grouping in global governance?, Diplo, (2017), in https://www.diplomacy.edu/blog/mikta-sustainablemiddle-power-grouping-global-governance

4. Çolakoğlu Selçuk, MIKTA's Role in the G20 (2016), in http://www.asianpacificcenter.org/mikta-s-role-in-the-g20.html

5. Colakoglu Selcuk, The Role of MIKTA in Global Governance: Assessments \& Shortcomings, "Korea Observer", 2016, Vol. 47, No. 2, pp. 267-290.

6. Çolakoğlu, Selçuk, Has MIKTA augmented the global governance role of middle powers?, "The Global", 2018, in https://theglobal.blog/2018/05/29/has-miktaaugmented-the-global-governance-role-of-middle-powers

7. Cooper Andrew Fenton, Dal Emel Parlar, Positioning The Third Wave Of Middle Power Diplomacy: Institutional Elevation, Practice Limitations, "International Journal", 2016, Vol. 71, No. 4, pp. 516-528. 
8. Cooper Andrew Fenton, MIKTA and the global projection of middle powers: Toward a summit of their own?, "Global Summitry", 1, 2015, Vol. 1, No. 1, pp. 95-114.

9. Dal Emel Parlar, Kurşun Ali Murat, Assessing Turkey's middle power foreign policy in MIKTA: Goals, means, and impact, "International Journal", 2016, Vol. 71, No.4, pp. 608-629.

10. Dal Emel Parlar, On Turkey's Trail as a "Rising Middle Power" in the Network of Global Governance: Preferences, Capabilities, and Strategies, "Perceptions", 2014, Vol. XIX, No. 4, pp. 107-136.

11. Engin Belma, Baba Gürol, MIKTA: A Functioning Product of "New" Middle Powerism?, "Review of International Law \& Politics", 2015, Vol. 11, No. 42, pp. 1-40.

12. Evans Gareth, Middle Power Diplomacy, Lecture in Chile Pacific Foundation, Santiago, 2011, in http://www.gevans.org/speeches/speech441.html

13. Fahamu Networks for Social Justice, MIKTA: A global vision of middle powers, in http://www.fahamu.org/ep_articles/mikta-a-global-vision-of-middle-powers/

14. Flake Gordon, Wang Xu, MIKTA: The Search for a Strategic Rationale (2017), in https://perthusasia.edu.au/getattachment/Our-Work/MIKTA-The-Search-For-A-Strate gic-Rationale/MIKTA-report-June-2017.pdf

15. Gök Gonca Oğuz, Karadeniz Radiye Funda, Emerging Middle Powers in Global Political Economy: Preferences, Capabilities and their Limitations, in Dal Emel Parlar (eds), Turkey's Political Economy in the 21st Century. International Political Economy Series. Palgrave Macmillan, 2020, p. 163-194.

16. Ikenberry Gilford John, The end of liberal international order?, "International Affairs", 2018, Vol. 94, No. 1, pp. 7-23.

17. IMF, World World Economic Outlook Database, in https://www.imf.org/en/ Publications/WEO/weo-database/2020/October/weo-report?c=193,536,542,273,186, $\& s=G G X W D N \_N G D P, \& s y=2009 \& e y=2019 \& s s m=0 \& s c s m=1 \& s c c=0 \& s s d=1 \& s s c=0 \& s i c=0$ $\&$ sort $=$ country $\& \mathrm{ds}=. \& \mathrm{br}=1$

18. Jadhav Pravin, Determinants of foreign direct investment in BRICS economies: Analysis of economic, institutional, and political factor, "Procedia - Social and Behavioural Sciences", 2017, Vol. 37, pp. 5-14.

19. Jongryn Mo, Introduction: G20 Middle Powers (MIKTA) and Global Governance, pp. 1-13, in Mo Jongryn (Ed.), MIKTA, Middle Powers, and New Dynamics of Global Governance The G20's Evolving Agenda, New York: Palgrave Macmillan, 2015.

20. Karadeniz Radiye Funda, 'The Middle Power Moment' Revisited in Global Governance: A Chance for MIKTA's Legitimacy Crisis in Post-Pandemic World?, "Marmara University Journal of Political Science", Vol.8, 2020, Special Issues, pp. 22-39.

21. Karagöl Erdal Tanas, Kıtalar Arası Ekonomik Isşbirliği: MIKTA, "Seta Perspektif”, No. 62, 2014, pp. 1-5.

22. Klingebiel Stephan, MIKTA: What's in a name? The potential of middle power cooperation to strengthen global governance (2020), in https://www.undp.org/content/ 
seoul_policy_center/en/home/presscenter/articles/2020/mikta--what_s-in-a-name-the-potential-of-middle-power-cooperati.html

23. Lee Sook-Jong, Chun Chaesung, Suh HyeeJung, Thomsen Patrick, Middle Power in Action: The Evolving Nature of Diplomacy in the Age of Multilateralism, 2015, EAI Middle Power Diplomacy Initiative (MPDI), East Asia Institute, pp. 1-29, in https://www.files.ethz.ch/ isn/191150/3 0.04.2015.pdf.

24. Lee Jong-Wha, The Republic of Korea's Economic Growth and Catch-Up: Implications for the People's Republic of China. ADBI Working Paper, 2016, No. 571, in https://www.adb.org/sites/default/files/publication/183353/adbi-wp571.pdf

25. MIKTA Foreign Ministers, MIKTA Vision Statement, in www.mikta.org/ about/vision.php

26. MIKTA, New Innovation Partnership, in http://www.mikta.org/web/viewer.html? file=/images $/ 2020 \% 20$ MIKTA\%20Booklet.pdf

27. Missiroli Antonio, O'Sullivan Domhnall, BRICS - the next layer, "Issue Alert", European Union Institute for Security Studies, 2013, No. 38, in https://www.iss.europa.eu/sites/default/files/EUISSFiles/Alert_38_Next_BRICS.pdf

28. Nordea Trade Portal, South Korea: Economic and Political Overview (2020), in https://www.nordeatrade.com/fi/explore-new-market/south-korea/economicalcontex

29. Öniş Ziya, Kutlay Mustafa, Demokratik BRICS Ülkeler: Küresel Yönetişimin Yeni Aktörleri, 2013, in https://www.academia.edu/19557328/Ziya_\%C3\%96ni\%C5\%9F_ve_ Mustafa_Kutlay_Demokratik_BICS_\%C3\%9Clkeler_K\%C3\%BCresel_Y\%C3\%B6neti\%C5\% 9Fimin_Yeni_Akt\%C3\%B6rleri

30. Öniş Ziya, Kutlay Mustafa, The dynamics of emerging middle-power influence in regional and global governance: the paradoxical case of Turkey, "Australian Journal of International Affairs", 2017, Vol. 71, No.2, pp. 164-183.

31. Pakpahan Beginda, Can Indonesia Help MIKTA Thrive? (2018), in https://thediplomat.com/2018/04/can-indonesia-help-mikta-thrive/

32. Patrick Stewart M., Feng Asley, MIKTA in the Middle: A Little-Known Multilateral Group Turns Five (2018), in https://www.cfr.org/blog/mikta-middle-little-knownmultilateral-group-turns-five

33. Republic of Turkey Ministry of Foreign Affairs, MIKTA Foreign Ministers' Joint Statement on the COVID-19 Pandemic and Global Health, 9 April 2020, in http://www.mfa.gov.tr/covid-19-a-iliskin-mikta-bildirisi-hk.en.mfa

34. Robertson Jeffrey, South Korea's quandary: What to do about MIKTA?, "The Interpreter", 2018, in https://www.lowyinstitute.org/the-interpreter/south-koreaquandary-what-do-about-mikta

35. Robertson Jeffrey, Where next for MIKTA?, "The Interpreter", 2020, in https://www.lowyinstitute.org/the-interpreter/where-next-mikta

36. Rozman Gilbert, The Sino-U.S. National Identity Gap, Australia, and the Formation of an Asia-Pacific Community, "Asian Survey", 2014, Vol. 54, No. 2, pp. 343-366. 
37. Siow Maria, Mikta who? Covid-19 injects five 'middle power' countries with new sense of purpose (2020), in https://www.scmp.com/week-asia/politics/article/3104456/ mikta-who-covid-19-injects-five-middle-power-countries-new-sense

38. Thakur Ramesh, How Representative are BRICS?, "Third World Quarterly", 2014, Vol. 35, No. 10, pp. 1791-1808.

39. The World Bank, World Development Indicators, in https://databank.worldbank.org/source/world-development-indicators

40. United Nations Development Programme, Human Development Report 2020, The next frontier Human development and the Anthropocene, in http://hdr.undp.org/ sites/default/files/hdr2020.pdf

41. United Nations Development Programme, Human Development Report 2010, The Real Wealth of Nations: Pathways to Human Development, in http://hdr.undp.org/sites/ default/files/reports/270/hdr_2010_en_complete_reprint.pdf

42. WTO, World Commodity Profiles (2019), in https://www.wto.org/english/ res_e/statis_e/trade_profiles_list_e.htm 